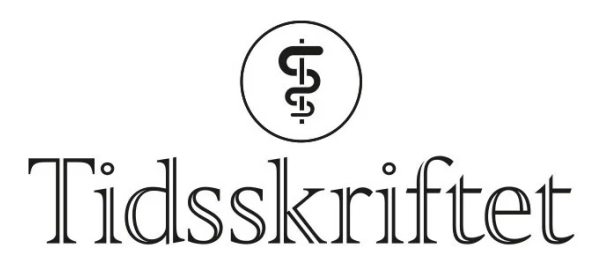

DEN NORSKE LEGEFORENING

\title{
De som står fremst
}

FRA REDAKTØREN

ARE BREAN

are.brean@tidsskriftet.no

Are Brean er sjefredaktør i Tidsskriftet. Han er ph.d. og spesialist i nevrologi.

\section{Helsearbeidere er på jobb der hvor smitterisikoen er høyest. De må beskyttes godt nok.}

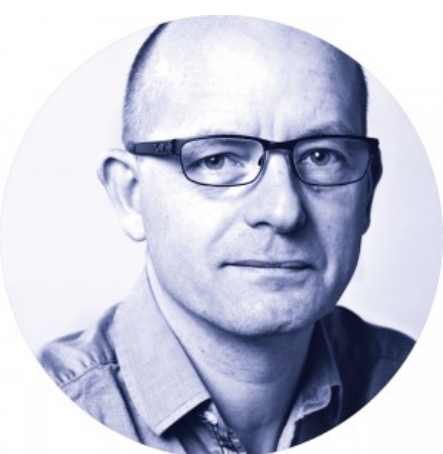

Foto: Einar Nilsen

Klinisk arbeid har alltid vært risikofylt: Hver dag handler om å ta beslutninger på usikkert grunnlag. Med covid-19-pandemien har risikoen fått et nytt og skremmende aspekt: Hver dag på arbeid øker risikoen for å pådra seg smitte - og for å bringe den videre til andre pasienter eller hjem til egen familie. Det personlige ansvaret for helsearbeidere oppleves plutselig tredobbelt med ansvar for både pasientenes, egen og egne nærståendes helse.

Smitterisikoen er i høyeste grad reell. I Kina opplevde man i stor utstrekning at smitte ble overført fra helsepersonell til familiemedlemmer (1). I Italia er inntil midten av april 2020 nærmere 17000 helsearbeidere smittet, og minst 125 leger har mistet livet (므). I enkelte stater i USA utgjør på samme tidspunkt helsearbeidere så mye som $20 \%$ av alle smittede (3). I Storbritannia er antallet helsearbeidere døde av covid-19 minst 96 (4). Mørketallene antas overalt å være store. Risikoen har også et kjønnsaspekt: I USA er 73 \% av covid-19-syke helsearbeidere kvinner (3), og i Italia er to tredjedeler av alle smittede helsearbeidere kvinner ( $\underline{2})$.

Samfunnet har et åpenbart moralsk ansvar for sine helsearbeideres sikkerhet - det er de som står fremst, og de som i samfunnets tjeneste daglig møter den høyeste smitterisikoen. Tragisk nok er det her det har sviktet i mange land. Mangelen på smittevernutstyr i helsevesenet har mange steder vært prekær. En undersøkelse utført i Storbritannia viste at nærmere halvparten av sykehuslegene som gjennomførte aerosolskapende prosedyrer hos 
covid-19-pasienter, manglet tilstrekkelig verneutstyr, og at nærmere halvparten av allmennlegene ikke hadde tilstrekkelig tilgang på standard munnbind (5). Italienske leger advarer om at mangel på smittevern for helsearbeiderne kan føre til kollaps i helsevesenet (ㅁ). Og i USA protesterer helsearbeidere over hele landet mot en omfattende mangel på elementært smittevernutstyr (7.).

\section{"Gitt de internasjonale erfaringene er det forstemmende at vi heller ikke $i$ Norge har maktet å tilstrekkelig beskytte de som står fremst $i$ virusstriden»}

Gitt de internasjonale erfaringene er det forstemmende at vi heller ikke i Norge har maktet å tilstrekkelig beskytte de som står fremst i virusstriden. I midten av april 2020 rasjonerte noen av landets største helseforetak, Oslo universitetssykehus (OUS) og Akershus universitetssykehus (Ahus), personlig smittevernutstyr til helsearbeidere, samtidig som sykepleiere daglig rapporterte om mangel på elementært utstyr som åndedrettsvern og munnbind ( $\underline{8}) \cdot 57 \%$ av helsearbeidere i Oslo som besvarte en undersøkelse i regi av Fagforbundet, hadde følt seg utrygge på jobb på grunn av pandemien, mens $36 \%$ hadde opplevd brudd på smittevernreglene på arbeidsplassen (9.). Og på St. Olavs hospital i Trondheim førte mangelen på elementært smittevernutstyr til at sykehuset ikke kunne gå

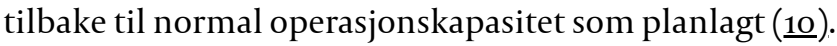

Vi hadde ingen overkapasitet i helsevesenet før dette begynte. Helsevesenet skal fortsette å behandle syke så lenge pandemien varer, og ikke minst etterpå. Derfor handler det ikke bare om samfunnets og arbeidsgivernes juridiske og moralske plikt til å beskytte helsearbeiderne. Det handler også om å sikre helsevesenets kapasitet. Og det handler om helsearbeidernes tillit til det systemet de er en del av. I Storbritannia har myndighetenes manglende evne til å beskytte sine helsearbeidere fordypet kløften av mistillit mellom helsearbeidere og myndigheter i et allerede hardt prøvet National Health Service (NHS) (4, 5). Slike erfaringer må tas på alvor. Dette er ikke tidspunktet for helsemyndighetene til å stille urealistiske krav til sykehusene om å håndtere både pandemien og etterslepet av annen behandling samtidig (11), eller til å holde fast på en finansiering som gjør at


mest, at tilliten settes på prøve.

I en tid der hundretusener av andre arbeidstagere tvinges ut av jobb for å minske smitterisiko, må helsearbeidere gå på jobb der hvor smitterisikoen er aller høyest. Ja visst er de helter. Men de er sårbare helter - og vi plikter å beskytte dem.

\section{LITTERATUR}

1. Adams JG, Walls RM. Supporting the health care workforce during the COVID-19 global epidemic. JAMA 2020;323: 1439-40. [PubMed][CrossRef]

2. Nærmere 17.00o helsearbeidere smittet i Italia. Nettavisen 17.4.2020. https://www.nettavisen.no/nyheter/utenriks/naermere-170oo-helsearbeidere-smittet-iitalia/3423955141.html Lest 22.4.2020.

3. Jewett C, Szabo L. Coronavirus is killing far more US health workers than official data suggests. The Guardian 15.4.2020. https://www.theguardian.com/us-news/2020/apr/15/coronavirus-us-health-careworker-death-toll-higher-official-data-suggests?CMP=series_embed_box Lest 22.4.2020.

4. Marsh S. Doctors, nurses, porters, volunteers: the UK health workers who have died from Covid-19. The Guardian 21.4.2020. https://www.theguardian.com/world/2020/apr/16/doctors-nurses-portersvolunteers-the-uk-health-workers-who-have-died-from-covid-19 Lest 22.4.2020.

5. Rimmer A. Covid-19: doctors still do not have \#properPPE. BMJ 2020;369: m1423. [PubMed] [CrossRef]

6. Lintern S. Coronavirus: Italian doctors warn protective equipment vital to prevent healthcare system collapse. The Independent 30.3.2020. 
https://www.independent.co.uk/news/health/coronavirus-italy-doctors-nhs-hospitals-ppea9435891.html Lest 22.4.2020.

7. Jeffery A. Healthcare workers protest for vital protection equipment. CNBC 18.4.2020. https://www.cnbc.com/2020/04/18/healthcare-workers-protest-for-vital-protection-equipment.html Lest 22.4.2020.

8. Lofstad R, Dønvold-Myhre L, Dorholt I. Sykepleiere er redde. Dagbladet 21.4.2020. https://www.dagbladet.no/nyheter/sykepleiere-er-redde/72373439 Lest 22.4.2020.

9. Fossheim K, Fjelltveit I, Braaten M et al. Føler seg utrygge på jobb: - Fikk beskjed om å bruke skotrekk som munnbind. TV2.no 13.4.2020. https://www.tv2.no/nyheter/11370439/ Lest 22.4.2020.

10. Dommerud T. Sykehusene forbereder seg på normal drift. Mangel på smittevernutstyr gjør det vanskelig. Aftenposten 16.4.2020. https://www.aftenposten.no/norge/i/Adw92q/sykehuseneforbereder-seg-paa-normal-drift-mangel-paa-smittevernutstyr-gjoer-det-vanskelig? Lest 22.4.2020.

11. Fagereng K, De Romijn B. Urealistisk oppdrag til sykehuset fra helseminister Bent Høie. Stavanger Aftenblad 19.4.2020. https://www.aftenbladet.no/meninger/debatt/i/naxxox/urealistisk-oppdrag-tilsykehuset-fra-helseminister-bent-hie Lest 22.4.2020.

12. Klev NK. Paradoksalt med permitteringer i fastlegetjenesten. Dagens Medisin 21.4.2020. https://www.dagensmedisin.no/artikler/2020/04/21/paradoksalt-med-permitteringer-ifastlegetjenesten/ Lest 22.4.2020.

Publisert: 4. mai 2020. Tidsskr Nor Legeforen. DOI: 10.4045/tidsskr.20.0360

(C) Tidsskrift for Den norske legeforening 2023. Lastet ned fra tidsskriftet.no 26. april 2023. 